\title{
A NYÍLT KORMÁNYZATI ADATOK KUTATÁSI KIHÍVÁSAI
}

Habár a nyílt adatok koncepciója már régóta ismert, komolyabb praktikus érdeklődésről a közszféra részéről körülbelül egy évtizede lehet beszélni. Ez a momentum megmozgatta az e-kormányzás 'fősodrába' tartozó kutatók érdeklődését is, mely meg is látszik a vonatkozó publikációk megemelkedett számán. Habár két-három éve visszaesni látszott a lendület, az újrahasznosítás jelensége újabb muníciót szolgáltatott a kutatásoknak. Jelen tanulmány a legfrissebb irodalom és esettanulmányok segítségével tekinti át a nyílt kormányzati adatok kutatásának jellemző területeit és javaslatokat fogalmaz meg olyan kutatási kérdésekre, melyek nemcsak előrébb vihetik a nyílt kormányzati adatok újrahasznosításának kérdéseit, de irányt mutathatnak hazai kutatóknak is a sikeres nemzetközi megjelenéshez.

Kulcsszavak: nyílt adatok, nyílt kormányzati adatok, nyílt adatok újrahasznosítása, kutatási program, kutatási kérdések

A 'nyílt adatok' kezdeményezés mint az e-Kormányzás fontos eleme került be a közszféra nyilvánosságot szolgáló eszköztárába (Dawes - Helbig, 2010). Elsődleges jelentése a közigazgatási, illetve kormányzati szerveknél és egységeknél keletkező adatok elérhetővé tétele jellemzően internetes csatornákon keresztül (Lindman et al., 2013), melynek fó célja az átláthatóság és elszámoltathatóság biztosítása (Janssen, 2011). Tipikus példák közé tartozik a közbeszerzéshez kapcsolódó adatok - felhívások, szerződések, tételek és összegek - elérhetővé tétele. De jelentős mennyiségű közadat áll rendelkezésre más területeken is, mint pl. a különböző hatósági eljárások, vagy közigazgatási feladatok ellátása során keletkezett adatok. Az elsődleges (azaz közszférán belüli) felhasználás után ezek az adatok további hasznosításra is érdemesek lehetnek. Juhász (2017) megemlíti a gazdasági, társadalmi, demográfiai és egészségügyi információkat, de ide sorolhatók a jogi vagy építésügyi adatok is. A közszféra adatainak innovatív, hozzáadott értéket képviselő piaci szolgáltatásokban való újrafelhasználása mára már több országban mindennapos gyakorlattá vált (Lindman et al., 2013). Ennek megfelelően a kutatói érdeklődés is felélénkült. Számos modell és keretrendszer látott napvilágot, vagy került újrahasznosításra - mint pl. az ökológiai rendszer metaforájának alkalmazása a nyílt adatokat érintő komplex jelenségek és szereplők viszonyainak leírására (Harrison et al., 2012). Habár számos irányban folynak kutatások a nyílt adatok újrahasznosításához kapcsolódó egyes kérdések megválaszolására (Zuiderwijk et al., 2014; Susha et al., 2017), még mindig nem tisztázott, mik az érdekes trendek és nyitott kutatási kérdések az előttünk álló évtizedre. Jelen cikk arra keresi a választ, hogy melyek azok a fontos kutatási kérdések a nyílt kormányzati adatok terén, melyek ígéretesek lehetnek hazai kutatók számára is.

A bevezetés után röviden áttekintjük a nyílt kormányzati adatok (NyKA) történetét és bemutatjuk a jelenlegi legelterjedtebb és legnépszerübb NyKA modelleket és elemzési keretrendszereket. Ezt követően összefoglaljuk az open data kutatás magyar viszonylatú publikációit. Az alkalmazott módszertan bemutatása után releváns irodalom segítségével összeszedjük milyen kutatási területeket különböztethetünk meg. Erre építve felvázoljuk saját javaslatunkat, majd ezt követően azonosítjuk az egyes területek nyitott kérdéseit. A cikk a hazai kutatás szempontból fontosnak vélt javaslatok összefoglalásával zárul.

\section{Nyílt kormányzati adatok és kutatásuk}

A nyílt kormányzati adatok rövid története

A kormányzati adatok elérhetőségének szorgalmazása nem új, az USA-ban már a múlt század 50-es éveiben felvetődött a 'nyílt kormányzat' - akkor még elsősorban jogi - gondolata (Parks, 1957). Az elsődleges cél az elszámoltathatóság volt, és az érvelés szerint ennek érdekében a kormányzati adatoknak 'nyíltnak' kellene lenniük. Ez az elvárás él az ún. információszabadság elvében, illetve az információhoz való hozzáférés jogában (Janssen, 2011), mely egészen a kilencvenes évek közepéig a domináns motivációt jelentette az állam által birtokolt adatok megismeréséhez. Az Internet megjelenésével kibontakozó e-kormányzás programja újabb lendületet adott a kérdésnek, és az ezredfordulón számos országban jelentek meg kormányzati (adat) portálok (Sáez Martín, 2016). Szigorúan véve, a 'nyílt adat' mint sajátos jelentésü kifejezés, az Open Knowledge Foundation (OKF) 2006-os kiáltványától datálható (OKF, 2006; Davies - Perini, 2016), bár ez a felhívás elsősorban általános jellegű volt, azaz tudományos és egyéb adatokra is vonatkozott. Nyílt adatnak azt tekintjük, amit ,alapvetöen az ingyenesség, a teljeskörüség, a technikai nyíltság, a jogi nyíltság és a megtalálhatóság" jellemez (Kaiser, 2015, 70.o.). A 'nyílt kormányzati adatok' mint külön terület, pedig az XXI. század első évtizedének végén került fókuszba a 'nyílt kormányzás' program részeként (Obama, 2009; Bates, 2014). „A nyílt kormányzás lényege, hogy az állampolgároknakjoguk van hozzáférni a kormányzat által generált információkhoz, 
dokumentumokhoz, illetve a kormányzati eljárásokhoz" (Goda, 2011, 181.o.). Az elmúlt tíz évben aztán egyre több ország indított valamilyen szintű nyílt kormányzás programot és így folyamatosan nő az elérhető adathalmazok száma. Ugyanakkor - és ez különösen igaz a kormányok és intézményeik által generált vagy birtokolt adatokra - a „,nyilt adatok tényleges értékét az a többlet fejezi ki, ami az adatok (újra) felhasználása révén keletkezik" (Kaiser, 2015, 70.o.). Ez azt is jelenti, hogy a gazdasági felhasználás is nagyobb hangsúlyt kap az egyébként is erősödő társadalmi-politikai vonal mellett, mely utóbbi célja a demokratikus és kormányzati döntési folyamatokban való állampolgári részvétel erősítése. Európai kontextusban az Európai Bizottság 2003-as Public Sector Information (PSI) programja (2003/98/EK irányelv), majd az azt megerősítő 2010-es Digital Agenda (EC, 2011) kezdeményezés ad kereteket a nyílt (kormányzati) adatok publikálásához és azok gazdasági-társadalmi felhasználásához. Az európai nyílt adat portál áttekintést ad a különböző tagállamok érettségéről és számos kapcsolódó indikátort megfogalmaz (lásd pl. https://www.europeandataportal.eu/en/dashboard\#2017).

\section{A nyílt kormányzati adatok kutatása során használt értelmezési keretek}

Már a kilencvenes évek elején felmerült, hogy a (szervezeti) adatok kezelésének folyamata, illetve tevékenységei összevethetők a fizikai termékek gyártási, logisztikai folyamataival (Wang et al., 1995) és megszületett az 'adatellátási lánc' fogalma, mely az adatok keletkezését, rögzítését, tárolását és felhasználását a termelö-szállító-fogyasztó metafora köré építi fel.

Az e-kormányzással megjelenő első internetes adatnyilvánossági megoldások elsősorban technikai oldalról közelítették meg a problémát és 'platform' megoldásokat alkalmaztak, ahol (egyes) kormányzati adatok publikálhatók - azaz egyirányú forgalomról beszélhetünk. Ebből fejlődtek ki, még mindig elsősorban technikai megoldásként, a portálok, melyek jellemzően API-kat (interfészeket) biztosítanak, melyekkel adott (esetleg többféle nyelven) lekérdezések is végezhetők. Ezt követték az interaktívabb, már visszajelzéseket lehetővé tévő (2.0-ás) megoldások (DiNucci, 1999; De Kool - Van Wamelen, 2008).

Az adat ellátási lánc megközelítésnek egyik legfontosabb célja az volt, hogy alkalmazni lehessen a gyártási folyamatok minőségbiztosítási modelljeit (Wang - Strong, 1996). Az ezredfordulóra a nyílt adatok egyik általános elvárása lett a források és az adathalmazok közötti kapcsolatok kezelése. Az ún. kapcsolt nyílt adatok (Linked Open Data) egyik legismertebb érettségmérő megközelítése lett a 5-star (öt csillagos) modell, melynek fókuszában a géppel olvashatóság és a lekövethetőség állt (Pignotti et al., 2011.). Később Groth (pl. 2013) az NyKA fontos kérdéseként jelölte meg, hogy ki felelős az adatok minőségéért (és a hibákért) és az adatok forrása mennyire menedzselt megfelelően. Ebben az értelemben az ellátási lánc az adatok létrehozásával kezdődik, melyet aztán tovább lehet adni, illetve kombinálni más adat(halmaz)okkal, illetve az adatok további átalakításon eshetnek át, míg eljutnak a végső felhasználóhoz (Li et al., 2017). A sokféle forrásból származó különböző adatok, illetve adattípusok kombinálása van a Big Data koncepció középpontjában is, ahol e források kombinálása (Miller - Mork, 2013) járul hozzá a hozzáadott érték létrehozásához. Ez vezetett el az adatértéklánc metafora alkalmazásához, melyet szintén az ipari termelési modellek (Porter, 1985) mintájára alkottak meg. Ez az értelmezés jól illeszkedik a NyKA újrahasznosíthatóságának a kérdéséhez, hiszen annak végső célja valamilyen (társadalmi-gazdasági) érték létrehozása új, innovatív szolgáltatások révén.

Az adatellátási lánc és -értéklánc metaforák egy lehetséges kritikája, hogy az adatok mozgását, mozgatását egyfajta lineáris modell mentén írják le, ezért is alkalmazzák többen is inkább az ún. életciklusmodell az adatok területén - és természetesen a nyílt adatokra is (lásd pl. Parsons et al., 2011). Az adatéletciklus lényeges felismerése, hogy az adatok létrehozói egyúttal fogyasztók is egy más szempontból (és viszont). Leegyszerüsítve azt mondhatjuk, hogy míg az életciklus- és az ellátásilánc-megközelítések a termelők és fogyasztók (igény és ellátás) kapcsolódására fókuszál, addig az értéklánc-értelmezés figyel a kontextusra is, és fókuszában az adatelemek átalakításának folyamatai/tevékenységei állnak annak érdekében, hogy magasabb szintü információt állítsanak elö egy adott cél érdekében.

A korábban említett (alapvetően statikus) platformés portálmegoldások az adatok publikálását tekintik elsődlegesnek a közszféra szereplői szempontjából (mint kötelesség vagy törvényi elvárás, szabályozásnak való megfelelés). Az újrahasznosítás számos új szereplőt hoz be a képbe a 'fogyasztói' oldalon az innovatív hozzáadott érték érdekében. Ilyenek például a jobb (egyszerübb, rendezettebb) hozzáférést biztosítók, az adattisztítást végzők, az integrálók és (végül) a szolgáltatásfejlesztők (Lindman et al., 2013). A hozzáadott érték maga nem a végső cél, a lényeg a hatás, mely jelentkezhet gazdasági előnyben vagy szociális jólétben (Davies - Perini, 2016). Ezen összetett szerepeknek és viszonyoknak a megértése vezetett el a nyílt adat 'ökoszisztéma' megközelítés megjelenéséhez. Az ökológia alapelveit már az ezredforduló környékén alkalmazták a szervezeti információmegosztás jelenségeinek megértésére (Nardi - O’Day, 1999; Fedorowicz et al., 2004). Az információökológia az „emberek, gyakorlatok, értékek és technológiák rendszere egy adott sajátságos helyi környezetben", és ennek vizsgálata a fenti elemek kapcsolatainak leírásával és megértésével foglalkozik (Nardi - O’Day, 1999, 53.o.). Tehát szerepekről, feladatokról, viszonyokról kell nyilatkozni és bemutatni ezeket egy adott környezetben. Davenport és Prusak (1997) a következő elemeket adja meg egy információs ökológia részeiként: külső környezet, szervezeti környezet, információs környezet és ezeken belül az érintettek, stratégia, kultúra és viselkedés, elvek és szabályok, folyamatok és végül (technológiai) architektúra. Ezt a szemléletet teljesíti ki az ökoszisztéma modellje, melyet a nyílt adatok kapcsán először Parsons és munkatársai (2011) használtak. Elsősorban az adatéletciklus-megközelítésre építve definiálták az 'információ-ökoszisztémát', mely az „,adatokat 
gyüjtö, kezelö és felhasználó emberek és technológiák és azok viszonyrendszeré[nek]" (557.o.) a leírása. Kritikaként elmondható, hogy az ökoszisztéma szereplöivel, szerepeivel vagy folyamataival és tevékenységeivel foglalkozó müvek igen eltérő modellezési elemekre építenek.

\section{Nyílt kormányzati adatok kutatása Magyarországon}

Az utóbbi évek legjelentősebb folyamata az NyKA hozzáadott értéket teremtő szolgáltatásokban történő 'újrahasznosítása', melyre Magyarországon a 2011-es 'információszabadság' törvény', illetve a 2012-es 'újrahasznosíthatósági' törvény ${ }^{2}$ teremt alapot. A nemzeti infokommunikációs stratégia 2014-2020 (NFM, 2014) kiemelten kezeli a nyílt kormányzati adatok témakörét; a digitális állam pillér átfogó célja az állami érdekkörbe tartozó információk és tartalmak széles körü digitalizációja és nyilvános hozzáférhetővé tétele. A 1310/2015. (V. 21.) Korm. határozat értelmében elkészített ún. Fehér könyv ${ }^{3}$ a közadatok újrahasznosítását elősegítő egységes kormányzati adatpolitika megalapozó koncepcióját adja, de konkrét intézkedéseket is megfogalmaz, például a hazai adatipar kialakulásának ösztönzéséhez kapcsolódó feladatokat jelöl ki és egy adatpolitikai szervezetrendszer létrehozását javasolja, mely egy nemzeti közadat portál müködtetését is felügyeli. A kapcsolódó területek a digitális adatvagyon hozzáférhetővé tétele, az adatbázisok együttműködésének, átjárhatóságának erősítése, adattisztítási folyamatok elvégzése, a biztonságos adatcsere lehetőségének biztosítása.

A nyílt kormányzati adatokkal kapcsolatos hazai szakirodalom egyik része a kapcsolódó jogi és szabályozási környezet értékelésével foglalkozik, míg egy másik jellemző irány technológiai részkérdésekre koncentrál. Ződi (2015) vizsgálja a PSI irányelv érvényesülésének európai és magyar jellegzetességeit és a közadatok hasznosításának kihívásait elemzi. Az Irányelv érvényesülését akadályozó tényezőként azonosítja az alábbiakat ${ }^{4}$ : szerzői jogi akadályok, használhatatlan (nem nyílt, egyedi) formátumok, túlárazottság és a határköltség kiszámíthatatlansága, valamint a piacon versengő (és a komparatív előnyükkel visszaélő) közszervezetek. Szőke (2018) a közadatok újrahasznosításának és az információszabadságnak hazai szabályozási környezetét hasonlítja össze, jogi szempontból vizsgálja a különbségeket, hasonlóságokat és a kapcsolódási pontokat. Goda (2011) a kormányzati adatok megnyitását szemléltető, nemzetközi müködő megoldásokat mutatja be. Munk et al. (2014) áttekintik a szabályozási hátteret az Európai Unióban és Magyarországon, összevetik a kapcsolt, nyílt kormányzati adatok megjelenését, helyét és szerepét az EU-s és a magyar szabályozásban és gyakorlatban, továbbá ismertetik a nyílt kormányzati adatok fogalmi alapjait is. A szerzők kitérnek a technológiai és informatikai háttér bemutatására és kutatási célokat és feladatokat azonosítanak a vizsgált területeken. A technológiai oldalon az egyik vizsgált terület a kapcsolt adatok alkalmazása (lásd pl. Micsik et al., 2014, vagy Szász et al., 2014) míg egy másik jellemző terület a nyílt adatok adatbiztonsági kérdései (pl. Fleiner, 2014).
Az elmúlt hat évben magyar szerzők tizenhárom cikket publikáltak ,nyílt adat” témában - ebből öt készült angol nyelven, melyből egy jelent meg nemzetközi folyóiratban (a többi jellemzően konferenciakiadványban). E tucatnyi cikk összesen tizenöt szerző tollából született, és három szerzőnek van egynél több cikke (jellemző a sokszerzős publikálás, ami jól mutatja a terület multidiszciplináris jellegét). A tizenhárom cikkből hat technikai jellegű (két esettanulmány és négy technikai-technológiai részletekkel, illetve adatbiztonsággal foglalkozó mü), míg hat jogi témájú. A Vezetéstudomány folyóiratban a közigazgatás, államigazgatás témakörben tizennyolc cikket publikáltak 2012-től, de ezek a cikkek nem vizsgálják a nyílt kormányzati adatok témakörét.

A hazai szakirodalom elmúlt hat évének elemzése rávilágít arra, hogy a nyílt kormányzati adatok témakörét a kutatók elsődlegesen jogi-szabályozási kérdésként vagy technikai-technológiai problémaként kezelik. Más szempontok pl. szervezeti kérdések vagy a hatások vizsgálata nem jellemző, és a kapcsolódó kutatási kérdések holisztikus megközelítése is hiányzik. Tekintetbe véve tehát a nyílt adatok kutatásának magyar nyelvü irodalmát, valamint a nemzetközi kutatások jelenlegi 'frontvonalát' (többek közt az alkalmazott értelmezési modellek bizonytalanságait), szükséges lenne egy átfogó kutatási keretrendszer kijelölése, mely jól körülhatárolható (rész) területeken belül tesz fel időszerű és tudományos érdeklődésre számot tartó kérdéseket, melyek ígéretesek lehetnek hazai kutatók számára is.

\section{Módszertani megfontolások}

\section{Kutatási kérdések}

A fent megfogalmazott kutatási célból következően, illetve figyelembe véve a téma magyar szerzőinek elérhető irodalmát, jelen kutatás a következő fö kérdésre fókuszál: 1) Melyek a legégetőbb, itthon még meg nem válaszolt kutatási kérdések az NyKA területén, melyek nemzetközi érdeklődésre is számot tarthatnak? Ehhez két segédkérdést állítottunk fel: 2.a) Milyen struktúra, holisztikus szempontrendszer alapján érdemes rendszerezni a szakirodalomban meghatározott kutatási területeket? 2.b) Melyek a szakirodalmi elemzés alapján a meghatározó, fontos és érdekes kutatási kérdések a nyílt kormányzati adatok szakterületen?

\section{Kutatási stratégia:}

\section{szisztematikus irodalomelemzés}

Kutatásunk módszertani alapját a szakirodalom elemzése adta, melyet a vom Brocke és szerzőtársai (2009) által javasolt módszertani modell szerint hajtottunk végre. Keretrendszerük öt részfolyamatot különböztet meg: 1) a szakirodalom-elemzési kutatás határainak kijelölése, 2) a kutatási téma fogalmi leírása, 3) keresés a szakirodalomban, 4) a szakirodalom elemzése és 5) a kutatási irányok kijelölése. A kutatás határainak kijelölése kritikus lépés, mivel meghatározza a további részfolyamatokat, ezért további támogató modellek alkalmazására lehet szükség. Ilyen a Cooper-féle taxonómia (Cooper, 1988), amely 
hat dimenzió mentén segít definiálni a kutatás határait. Ezek a kutatás fókusza, célja, szervezése, nézőpontja, felhasználói köre és a lefedettsége. Kutatásunkban a vom Brocke-modellt az alábbi módon alkalmaztuk. A kutatás határainak kijelölése során a nyílt kormányzati adatok szakterületet választottuk ki. Az első lépésben alkalmaztuk a Cooper-féle taxonómiát is, amely szerint kutatásunk fókusza a nyílt kormányzati adatok szakterületen a szakirodalomban azonosítható kutatási eredmények áttekintése; a cél a kapcsolódó szakirodalom kritikai elemzése. Fogalmi/elméleti kérdésekkel foglalkozunk, nézőpontunk semleges, a felhasználói kör az akadémiai közösség és a közszférában dolgozó szakemberek, a szakterületi lefedettség pedig reprezentatív, ami a vom Brocke-féle modellben azt jelenti, hogy a témában rendelkezésre álló cikkekből vett minta alapján vonunk le következtetéseket a teljes korpuszra vonatkozóan. A vom Brocke-modell második lépése a kutatási téma fogalmi leírása, amely történhet terminológia, taxonómia, vagy akár ontológia segítségével. Ebben a lépésben javasolják a kulcskifejezések összegyüjtését és definiálását is, ezt a cikk második és harmadik fejezete tartalmazza. A harmadik részfolyamat a keresés a szakirodalomban. Ez a mi esetünkben a Scopus adatbázisban és a Google Scholar-ban történő keresés volt az „open government data” (483/7760) kifejezés és a felsoroltak közül valamelyik további kifejezés használatával (zárójelben a két adatbázis találatai): „literature review” (89/1260), „research agenda” (98/488), „taxonomy” (24/681), „overview” (84/3070), „history” (32/2380) vagy „research framework” (2/138). A keresést elvégeztük a magyar nyelvü kifejezésekre is. Míg a Scopus egy fizetős szolgáltatás és egy adott kiadó szemléletét tükrözi, addig a Scholar mondhatni a másik végletet képviseli, hiszen szinte minden, az Interneten elérhető mű (és hivatkozások) feltérképezésére kiterjed (és így további szüréseket igényel) - ugyanakkor a Scholar nagy előnye, hogy fizetős tartalmaknak elérhető a szerzői változata is. A találati eredményekből az elmúlt tizenöt év cikkeit tartottuk meg, azokat amelyek (a cím vagy a kivonat alapján) a) kutatási kérdéseket, irányokat vázoltak fel, b) terminológiát, taxonómiát adtak meg, c) történeti áttekintést tartalmaztak, d) szakirodalom elemzést/áttekintést tartalmaztak, vagy e) a szabályozási környezetet írták le. Az így leszűkített 127 elemböl álló szakirodalmi lista mélyebb vizsgálata után két szakterületi szakértő (a cikk szerzői) olvasta el és dolgozta fel a kiválasztott 12 cikkből álló reprezentatív mintát, majd adta meg azok besorolását az 1. táblázatban bemutatott szempontrendszer szerint.

\section{Az irodalomban bemutatott kutatási területek}

A fent ismertetett feltételeknek megfelelö tudományos cikkek számos szakterület szempontjából tekintik át a nyílt kormányzati adatok kutatási problémáit. Az elmúlt mintegy tizenöt évben számos próbálkozás született arra is, hogy áttekintsék az NyKA múltját, változásait, és felvázolják a lehetséges fejlődési irányokat is. Az egyes cikkek szemlélete és fókusza eltérö, de együtt adhatnak átfogó képet, ugyanakkor első lépésként egy közös értelmezési tartományra kellett hozni őket egy egységes területi lista kialakításával.
Arzberger et al. (2004) az elsők között foglalkoztak a nyílt adatok újrahasznosításának kérdésével tudományos alapokon. Tanulmányuk az OECD megbízásából készült és a közpénzből finanszírozott kutatási eredményeket tartalmazó adatbázisok megnyitásának lehetőségeit vizsgálták. Öt területet javasoltak az adatok elérhetősége szempontjából: technológiai, szervezeti és menedzselési, pénzügyi és költségvetési, jogi és szabályozási, valamint kulturális és viselkedési. Harrison et al. (2012) a nyílt kormányzás koncepcióját helyezték vizsgálatuk középpontjába és négy területet tartottak fontosnak: stratégia és gyakorlat, felhasználók, technológia és innováció, illetve kontextus (amibe beleérthető a jogi, szabályozási és gazdasági környezet). E területeken belül pedig hat témát jelöltek meg, melyek kapcsolódnak a nyílt adatok problémaköréhez: a fontos adatok azonosításának folyamata, az adatgyüjtés prioritásainak megállapítása, adatgyűjtés, adatok publikálása, adatok felhasználása, és értékteremtés. Lindman et al. (2013) a nyílt adatokra épített szolgáltatások kutatására fókuszáltak és kutatási javaslatukban hét kategóriába sorolták az azonosított kihívásokat: információ, technológiák, folyamatok és tevékenységek, termékek és szolgáltatások, résztvevők, ügyfelek és környezet. A nyílt adatokhoz kapcsolódó innovációk vizsgálata közben Zuiderwijk et al. (2014) áttekintették a vonatkozó szakirodalmat és hét kutatási perspektívát tártak fel: szabályozási, politikai, szociális, gazdasági, szervezeti, működtetési és technikai. E perspektívák vizsgálata kapcsán három fö kutatási irányt jelöltek meg: elmélet és fejlesztés, szabályok, használat és innováció, valamint infrastruktúra és technológiák. Habár nem elsődlegesen a nyílt adatokra koncentrál, de az ún. CROSSROAD nyílt kormányzás kutatási taxonómia (pl. Lampathaki et al., 2010) is fontos mérföldkő és hasznos adalékkal szolgál e kutatáshoz, amennyiben tizenhét területet sorol öt kutatási téma alá: nyílt kormányzati információk a transzparencia szolgálatában, állampolgári részvétel, szabályozás modellezés, kormányzati bizalom és a személyes adatok menedzselése, illetve a jövő Internete a kormányzásban. Davies és Perini (2016) a nyílt adatok hatását vizsgálták és négy területet azonosítottak, melyre a kutatások koncentrálnak: a nyílt adatok története, felkészültség értékelése, implementációs esettanulmányok és hatások vizsgálata. Charalabidis et al. (2016) számos kutatási programjavaslatot dolgoztak fel (köztük négyet a fentiekből) egy egységes NyKA kutatási taxonómia összeállítása érdekében, és azok alapján harmincöt kutatási témát vázoltak fel négy összefoglaló terület alatt (menedzselés és szabályozás, infrastruktúrák, használat és érték, valamint interoperabilitás). Hossain et al. (2016) a nyílt adatok irodalmának átfogó áttekintése kapcsán javasoltak kutatási programot és négy fö gyakorlati területet különböztetnek meg: hajtóerők, akadályozó tényezők, előnyök és elméleti alapok. Styrin et al. (2017) az adat-ökoszisztéma szempontjából hasonlított össze nemzetközi példákat és megállapításuk szerint az NyKA területének három fókuszpontja van, melyek a szabályozás és gyakorlat, adatmenedzsment, illetve az érintettek kezelése. Az egyik legújabb kutatási programot Kankanhalli et al. javasolták (a cikk 2017-ben 
jelent meg), melyben három kutatási irányt neveztek meg: szakterület-specifikus tanulmányok, az eszközök alkalmazásának vizsgálata, továbbá a jelenlegi elméleti alapok és kutatás módszertanok kiterjesztése. Susha et al. szintén 2017-ben publikált tanulmánya a szektorok közötti együttmüködés szempontjából javasolt egy nyílt adat taxonómiát és két csoportban tizennégy (hat és nyolc) dimenziót vezetett be: adatmegosztás (benne típus, tartalom, adminisztrációs szint, adatforrások változatossága, támogatás és a hozzáférés foka), illetve adatfelhasználás (célközönség, adatválasztás, szabályozási problémák, motiváció, folytonosság, kimenet, együttmüködés és szándék). Magyar szempontból Munk et al. (2014) tekintették át a kapcsolt nyílt adatok kutatásának hazai kihívásait és az uniós szabályozás kontextusában három területen fogalmaztak meg kérdéseket: kapcsolt nyílt adatok fogalmi és értelmezési kérdései, a hazai és uniós szabályozás viszonyrendszere, valamint a kapcsolt nyílt kormányzati adatok európai uniós és magyar alkalmazási területeinek elemzése (mely utóbbiba - számos téma mellett - beletartoznak a szemantikai és technikai kérdések is). Az elemzett cikkek által javasolt területeket az 1. táblázat foglalja össze.

\section{Javasolt kutatási területek és az azokon belül feltárt nyitott kérdések}

Figyelembe véve a szakirodalomban már felvetett irányokat, illetve azok átfedéseit, valamint a magyar publikációk tartalmának igen erősen jogi-szabályozási és technológiai dominanciáját, jelen tanulmány egy leegyszerüsített és kiegyensúlyozott területi felosztást mutat be, mely segítséget jelenthet egy hazai kutatási program felépítésében. Eszerint a nyílt adatok kutatási területei:

a. a kontextus: mely átfogja a jogi hátteret, a szabályozást és egyéb környezeti elemeket mint pl. a kormányzás (beleértve a nem szervezeti közigazgatási kérdéseket),

b. a közszféra intézményi oldala: ide tartoznak a résztvevők, szervezeti kérdések, döntések, folyamatok és szerepek - illetve konkrét esettanulmányok, országállapot-elemzések/jelentések/értékelések,

c. technológia és adat: melybe beletartozik a technológiai platform, szabványok, adattipológia, adatminőségi kérdések, adatminőség-elemző keret-

Nyílt kutatási adatok kutatási területei

1. táblázat az irodalomban

\begin{tabular}{|c|c|c|c|c|c|c|c|c|c|c|c|c|c|}
\hline Területek & 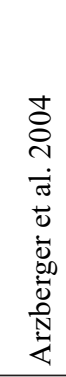 & 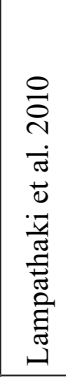 & 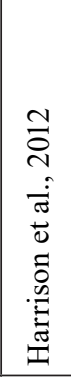 & 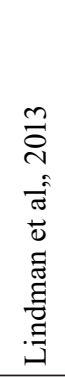 & 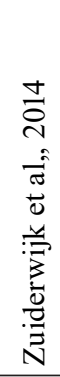 & 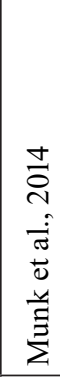 & 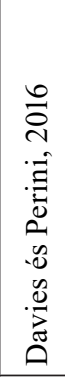 & 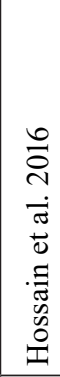 & 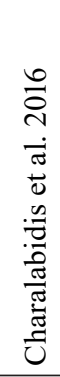 & 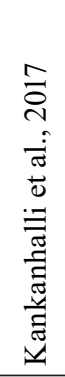 & 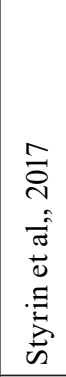 & 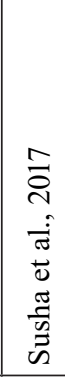 & 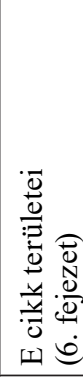 \\
\hline Nyílt adatok története & & & & & & & + & & & & & & $\mathrm{f}$ \\
\hline Politika & & + & & & + & + & + & & & & & & $\mathrm{a}$ \\
\hline Jog és szabályozás (környezet) & + & + & + & & + & + & + & & + & & + & + & $\mathrm{a}$ \\
\hline Pénzügy és költségvetés & + & & & & & & & & & & & & $\mathrm{a}$ \\
\hline Szervezet és menedzsment (felkészültség, ösztönzés) & + & + & & & + & + & + & + & + & & & + & $\mathrm{b}$ \\
\hline Kultúra és viselkedés & + & + & + & & & & + & & & & & + & $b$ \\
\hline Gyakorlat és megvalósítás (müködtetés) & & & + & & + & & + & + & & & + & & $\mathrm{b}$ \\
\hline Folyamatok és tevékenységek & & & & & & & & + & & + & & & $\mathrm{b}$ \\
\hline Szerepek és résztvevők (érintettek és együttmüködés) & & + & + & + & & + & & & & & + & + & $\mathrm{b}, \mathrm{e}$ \\
\hline Felhasználók, fogyasztók (felhasználás) & & + & & + & + & & & & + & & & & $\mathrm{e}$ \\
\hline Technológia és infrastruktúra (szabványok) & + & + & + & + & + & & & & + & + & & & $\mathrm{c}$ \\
\hline Információ & & + & & + & & & & & & & & + & $\mathrm{c}$ \\
\hline Adatmenedzselés & & + & & & & & & & & & + & + & $\mathrm{c}$ \\
\hline Termékek és szolgáltatások & & & & + & & & & & & & & & $\mathrm{d}$ \\
\hline Innováció & & & & & + & & & & & & & & $\mathrm{d}$ \\
\hline Hatások, haszon, érték & & & & & & & + & + & + & & & + & $\mathrm{e}$ \\
\hline Társadalom & & + & & & + & & & & & & & & $\mathrm{e}$ \\
\hline Elmélet & & & & & + & + & & + & & + & & & $\mathrm{f}$ \\
\hline Szakterületi alkalmazások & & & & & & & & & & + & & & $\mathrm{d}, \mathrm{e}$ \\
\hline
\end{tabular}


rendszerek, rendelkezésre állás (adatok köre és elérhetősége), a tényleges használhatóság és a kapcsolt adatok,

d. újrahasznositás: mely lefedi az adatok (direkt) felhasználását, az innováció kérdéskörét, valamint a hozzá adott értéket teremtő szolgáltatásokat,

e. végfelhasználók: mely nemcsak a nyílt adatok felhasználóit foglalja magában, hanem ide tartozik a (tényleges) társadalmi hatások vizsgálata is,

f. elmélet: mely jelenti az elméleti alapok vitáit, a terminológiai kérdéseket és a történeti áttekintéseket.

Az egyes témakörökre a feldolgozott irodalom alapján és a hazai helyzetet is figyelembe véve kutatási kérdéseket is javasolunk az alábbiak szerint.

Kontextus - Mivel a Munk et al. (2014) cikk kivételével nem készült olyan tanulmány, mely felmérné a magyar szabályozás jellegét és gyakorlatba ültetését, illetve összevetné ezeket más országok megoldásaival, így érdemes megvizsgálni: 1) Melyek a szabályozási környezet fontosabb elemei és ezek hogyan kapcsolódnak egymáshoz (milyen területekre vonatkoznak, van-e átfedés, milyen a hazai és nemzetközi szabályozás viszonya)? 2) A szabályozói környezet milyen informatikai alkalmazások fejlesztését teszi lehetővé a végfelhasználók segítése szempontjából?

A közszféra intézményi oldala - Az európai nyíltadatportál ugyan javasol egy érettségi modellt, de az a különböző tagállamok közadatportáljának érettségére vonatkozik (lásd https://www.europeandataportal.eu/sites/default/ files/country-factsheet_hungary_2017.pdf). A hazai intézmények számára kevés - nem kormányzati iránymutatás - létezik, így érdemes itt is a nemzetközi normák felöl elindulni: 1) Milyen megoldásokat alkalmaznak az EU-tagállamok intézményei a nyílt adatok kezelésére és melyek a legjobb gyakorlatok? 2) Milyen érettségi modelleket lehetne alkalmazni a meglévő gyakorlatok összehasonlítására?

Technológia és adat - Bár van hazai irodalma a technológiai (ide értve az adatokkal kapcsolatos) kihívásoknak és a kapcsolt adatok kérdéskörének, az alábbi általánosabb technológiai kérdések is felmerülnek: 1) Melyek a jellemző 'open data' architektúramegoldások, milyen előnyeik és hátrányaik vannak? 2) Melyek a vonatkozó szabványok és ezek hogyan kapcsolódnak egymáshoz? 3) Milyen végfelhasználói szolgáltatások segíthetik a szemantikus technológiák hasznosítását szélesebb körben (pl. a SPARQL lekérdezések ismerete nem feltétlenül várható el a felhasználótól)? 4) Hogyan mérhetjük a nyílt kormányzati adatok minőségét? 5) Milyen a magyarországi NyKA minősége nemzetközi összehasonlításban? Ehhez a kérdéshez részben kapcsolódik az európai nyílt adat portál magyar vonatkozású része, a használhatóság (usability), a készültség (readiness) és a hatás (impact) jellemzőkkel. 6) Hogyan tárhatók fel az NyKA kapcsán megjelenő adatminőségi problémák okai - és ezek a problémák hogyan kezelhetők? 7) A nyílt kormányzati adatok milyen és mekkora része esik 'Big Data' kategóriába és ennek az adatkörnek milyen speciális követelményei vannak?
Újrahasznositás - Több jogi utalás és javaslat mellett sem született nemzetközileg is jegyzett eredmény, pedig felfedezésre érdemes területek vannak, beleértve az egyre népszerübb 'okos' megoldások vonulatát is: 1) Milyen hasznosítási (üzleti) modellek vannak, és ezeket hogyan értékeljük? 2) E hasznosítási modellekben milyen megoldásokat javasolnak a licencek kezelésére (melynek természetesen jogi vonatkozásai is vannak)? 3) Miként lehetne megfoghatóvá tenni/mérni a hozzáadott értéket? 4) Milyen kapcsolatok léteznek a nyílt adatok és az okos város megoldások között és miként lehet ezeket fejleszteni?

Végfelhasználók - Ez nemzetközileg is még viszonylag kevéssé feltárt terület: 1) Milyen társadalmi hatásokat lehet beazonosítani? 2) Hogyan növelhető az eredmények hatásfoka (ez kapcsolódik a technológiai és a szervezeti területekhez is)?

Elmélet - A szakirodalom számos, a nyílt kormányzati adatok területéhez tartozó fogalmat tartalmaz, amelyeket nem mindig használnak egyforma értelmezésben. Vannak kísérletek, projektek a szakterület terminológiájának, taxonómiájának, ontológiájának létrehozására ${ }^{5}$ (lásd pl. Pattuelli, 2015; Southwick, 2015), de ezeknek a kutatásoknak a többsége nem épít más kezdeményezésekre, a helyi (pl. magyar) sajátosságokat nem veszi figyelembe. Kapcsolódó kutatási kérdések lehetnek: 1) Milyen minőségüek a jelenleg elérhető terminológiák, taxonómiák és ontológiák, hogyan értékeljük őket? 2) Milyen módszertant érdemes alkalmazni a terminológiák, taxonómiák és ontológiák fejlesztésében? 3) Milyen integrálási lehetőségek vannak a jelenleg elérhető terminológiák, taxonómiák és ontológiák esetében? 4) A jelenleg elérhető terminológiák, taxonómiák és ontológiák hasznosíthatók-e a magyar környezetben, milyen alkalmazásokat érdemes építeni rájuk?

\section{Összefoglalás}

Az utóbbi évek adatiparának növekedése robbanásszerü, a rendelkezésünkre álló digitális információ 90\%-a az elmúlt három-négy évben keletkezett. Az utóbbi időszakban egyre több kutatás helyezi középpontjába az adatipar kihívásait, ami alól nem kivétel a nyílt kormányzati adatok szakterülete sem. Tanulmányunk célja, hogy a legfrissebb szakirodalom alapján áttekintést adjon a nyílt kormányzati adatok kutatási területeiről, strukturálja azokat és javaslatokat fogalmazzon meg lehetséges további hazai kutatási irányokra. Cikkünkben ismertettük a nyílt kormányzati adatok szakterületének elméleti hátterét, bemutattuk a kapcsolódó kutatások során használt értelmezési modelleket. A hazai szakirodalom elemzése rávilágított arra, hogy a nyílt kormányzati adatok témakörét a magyarországi kutatók elsődlegesen jogi-szabályozási kérdésként kezelik. Míg egyes anyagokban megjelennek más szempontok pl. az informatikai kérdések is, a kapcsolódó kutatási kérdések és területek holisztikus megközelítése hiányzik. Cikkünkben egy ilyen holisztikus megközelítést dolgoztunk ki. A cikk egy átfogó szempontrendszert mutatott be, amelyben a feldolgozott szakirodalmat is elhelyezzük. A szakirodalom elemzése alapján, a kialakított szempontrendszer szerint újrarendeztük a kutatási területeket, és 
ezeken belül olyan kutatási kérdéseket fogalmaztunk meg, melyek szándékaink szerint gazdagíthatják a szakterület kutatási potenciálját. Számos érdekes kutatási területet sikerült azonosítani a nyílt kormányzati adatokkal kapcsolatosan, többek között ilyen az újrahasznosítás kérdésköre, illetve a társadalmi hatások vizsgálata. Tanulmányunk kiegészítheti a kapcsolódó területekre vonatkozó szakirodalom-elemzéseket, keretet adhat a nyílt adatokkal kapcsolatos kutatásoknak. Kutatásunkat az azonosított jövőbeli fejlesztési irányok közül elsősorban az elméleti kérdések, az adatökoszisztéma-szemlélet alkalmazása és a nyílt kormányzati adatok adatminőségi kihívásainak megértése mentén tervezzük folytatni.

\section{Jegyzet}

1 2011. évi CXII. törvény az információs önrendelkezésröl és az információszabadságról

2 2012. évi LXIII. törvény a közadatok újrahasznosításáról és annak módosításáról szóló 2015. évi XCVI. törvény

${ }^{3}$ http://nhit.hu/dokumentum/176/Adatpolitikai_feher_konyv_201608. pdf

${ }^{4}$ http://ec.europa.eu/information_society/newsroom/cf/dae/document. cfm?doc_id $=3852$

${ }^{5}$ http://data.europa.eu/euodp/en/linked-data

\section{Felhasznált irodalom}

Arzberger, P. - Schroeder, P. - Beaulieu, A. - Bowker, G. - Casey, K. - Laaksonen, L. - Wouters, P. (2004): An international framework to promote access to data. Science, 303(5665), p. 1777-1778. DOI: 10.1126/ science. 1095958

Bates, J. (2014): The strategic importance of information policy for the contemporary neoliberal state: the case of open government data in the United Kingdom. Government Information Quarterly, 31(3), p. 388-395. https://doi.org/10.1016/j.giq.2014.02.009

Charalabidis, Y. - Alexopoulos, C. - Loukis, E. (2016): A taxonomy of open government data research areas and topics. Journal of Organizational Computing and Electronic Commerce, 26(1-2), p. 41-63. https://doi.org /10.1080/10919392.2015.1124720

Cooper, H.- Hedges, L.V. - Valentine, J.C. (eds.) (2009): The handbook of research synthesis and meta-analysis. Russell Sage Foundation

Davenport, T. H. - Prusak, L. (1997): Information Ecology: Mastering the Information and Knowledge Environment. New York: Oxford University Press

Davies, T. - Perini, F. (2016): Researching the emerging impacts of open data: revisiting the ODDC conceptual framework. The Journal of Community Informatics, 12(2)

Dawes, S. S. - Helbig, N. (2010): Information Strategies for Open Government: Challenges and Prospects for Deriving Public Value from Government Transparency. In Wimmer, Chappelet, Janssen, and Scholl (Szerk.), 9th IFIP 8.5 Conference on Electronic Government, Springer LNCS-6228, p. 50-60.

De Kool, D. - Van Wamelen, J. (2008): Web 2.0: a new basis for e-government? In Proceedings of the 3rd International IEEE Conference on ICTTA, p. 1-7.
DiNucci, D. (1999): Fragmented Future. Print, 53(4), 32.

EC, European Commission (2011): Digital Agenda: Turning government data into gold. Online http://europa.eu/rapid/pressReleasesAction.do? reference $=\mathrm{IP} / 11 / 1524 \&$ format $=$ HTML\&aged $=$ 0\&language $=\mathrm{EN \& guiLanguage}=\mathrm{en}$. Letöltve 2015 május 20 .

Fedorowicz, J. - Gogan, J.L. - Ray, A.W. (2004): The ecology of interorganizational information sharing. Journal of International Information Management, 13(2), 1.

Fleiner, R. (2014): Kapcsolt nyílt kormányzati adatok biztonsága. Hadmérnök, 9(2), p. 267-276.

Goda, Sz. (2011): Nyílt adat és nyílt kormányzás. Információs Társadalom, XI(1-4), p. 181-187.

Groth, P. (2013): Transparency and reliability in the data supply chain. IEEE Internet Computing, 17(2), p. 69-71.

Harrison, T.M. - Pardo, T.A. - Cook, M. (2012): Creating open government ecosystems: A research and development agenda. Future Internet, 4(4), p. 900-928. https://doi.org/10.3390/fi4040900

Hossain, M.A. - Dwivedi, Y.K. - Rana, N.P. (2016): State-of-the-art in open data research: Insights from existing literature and a research agenda. Journal of Organizational Computing and Electronic Commerce, 26(1-2), p. 14-40. https://doi.org/10.1080/10919392.201 5.1124007

Janssen, K. (2011): The influence of the PSI directive on open government data: An overview of recent developments. Government Information Quarterly, 28(4), p. 446-456. https://doi.org/10.1016/j. giq.2011.01.004

Juhász, R. (2017): Versenyelöny közadattal. Lechner Tudásközpont; 2017. április 19. Közli: http://hirlevel. egov.hu/2017/04/23/ha-nyitva-van-az-adatkapuversenyelony-kozadattal/.

Kaiser, T. (2015): Nyílt kormányzat, nyílt adatok: a szabad hozzáféréstől a hatékony újrafelhasználásig. In: Dargay, E. és Juhász, L.M. (Szerk.): Antikorrupció és integritás. Budapest, NKE, p. 69-91.

Lampathaki, F. - Charalabidis, Y. - Passas, S. - Osimo, D. - Bicking, M. - Wimmer, M. A. - Askounis, D. (2010): Defining a taxonomy for research areas on ICT for governance and policy modelling. In: International Conference on Electronic Government, Springer, Berlin, Heidelberg, p. 61-72. https://doi. org/10.1007/978-3-642-14799-9_6

Li, P. - Wu, T.Y. - Li, X.M. (2017): Constructing data supply chain based on layered PROV. The Journal of Supercomputing, 73(4), p. 1509-1531.

Kankanhalli, A. - Zuiderwijk, A. -Tayi, G.K. (2017): Open innovation in the public sector: A research agenda. Government Information Quarterly, 1(34), p. 84-89. https://doi.org/10.1016/j.giq.2016.12.002

Lindman J. - Rossi, M. - Tuunainen, V. (2013): Open Data Services: Research Agenda. Proceedings of HICSS46, p. 1239-1246.

Micsik A.- Turbucz S. - Tóth, Z. - Sziládi Z. (2014): Linked Open Data: konverzió és vizualizáció. In: Nagy M. 
(szerk.): Networkshop 2014 Konferencia, Pécs (04.2304.25): CD, NIIFI, Paper 51, 5 p.

Miller, H.G. - Mork, P. (2013): From data to decisions: a value chain for big data. IT Profess., 15(1), p. 57-59.

Munk, S. - Fleiner, R. - Micsik, A. - Sikolya, Zs. - Nyáry M. (2014): Kapcsolt nyílt kormányzati adatok és kutatásuk keretei Magyarországon. Pro Publico Bono - Magyar Közigazgatás, 4, p. 144-169.

Nardi, B.A. - O’Day, V. (1999): Information ecologies - Using Technology with Heart. Cambridge, MA; London: MIT Press, (Chapter 4: p. 49-57).

NFM (2014): Nemzeti Infokommunikációs Stratégia 2014 2020. Nemzeti Fejlesztési Minisztérium, Budapest.

Obama, B. (U.S. Executive Office) (2009): Open government directive. Online, letöltve 2017. augusztus 7: http://www.whitehouse.gov/sites/default/files/omb/ assets/memoranda_2010/m2010/m10-06.pdf.

Open Knowledge Foundation (2006): Open Knowledge Definition. Online, letöltve 2017. szeptember 7: http:// www.opendefinition.org/.

Parks, $W$. (1957): The open government principle: applying the right to know under the constitution. The George Washington Law Review, 26(1), p. 1-22.

Parsons, M.A. - Godøy, Ø. - LeDrew, E. - De Bruin, T.F. - Danis, B. - Tomlinson, S. - Carlson, D. (2011): A conceptual framework for managing very diverse data for complex, interdisciplinary science. Journal of Information Science, 37(6), p. 555-569. https://doi. org $/ 10.1177 / 0165551511412705$

Pattuelli, M.C. - Provo, A. - Thorsen, H. (2015): Ontology building for linked open data: a pragmatic perspective. Journal of Library Metadata, 15(3), p. 265-294. https:// doi.org/10.1080/19386389.2015.1099979

Porter, M.E. (1985): Competitive Advantage: Creating and Sustaining Superior Performance. New York: Simon and Schuster

Pignotti, E. - Corsar, D. - Edwards, P. (2011): Provenance Principles for Open Data. In Proceedings of DE2011.

Sáez Martín, A. - Rosario, A.H.D. - and Pérez, M.D.C.C. (2016): An international analysis of the quality of open government data portals. Social Science Computer Review, 34(3), p. 298-311. https://doi. org $/ 10.1177 / 0894439315585734$

Southwick, S.B. - Lampert, C.K. - Southwick, R. (2015): Preparing controlled vocabularies for Linked Data: Benefits and challenges. Journal of Library Metadata,
15(3-4), p. 177-190. https://doi.org/10.1080/19386389.2 015.1099983

Styrin, E. - Luna-Reyes, L.F. - Harrison, T.M. (2017): Open data ecosystems: an international comparison. Transforming Government: People, Process and Policy, 11(1), p. 132-156. https://doi.org/10.1108/TG-012017-0006

Susha, I. - Janssen, M. - Verhulst, S. (2017): Data collaboratives as a new frontier of cross-sector partnerships in the age of open data: taxonomy development. Proc.s of the 50th Hawaii Int. Conf. on System Sciences

Szász, B. - Fleiner, R. - Micsik, A. (2014): Practical uses of location and event data as Linked Open University Data In: Kovács, E. - Kusper, G. - Juhász, T. - Tómács, T. (eds.): Proceedings of the 1st International Conference and Exhibition on Future RFID Technologies. Eger (11.05-11.07.), p. 151-159.

Szőke, G.L. (2018): Információszabadság és a közadatok újrahasznosítása: elhatárolás és kapcsolódási pontok. (Megjelenés alatt.)

vom Brocke, J. - Simons, A. - Niehaves, B. - Riemer, K. - Plattfaut, R. - Cleven, A. (2009): Reconstructing the Giant: On the Importance of Rigour in Documenting the Literature Search Process. In: Proceedings of ECIS 2009, Paper 161.

Wang, R.Y. - Storey, V.C. - Firth, C.P. (1995): A framework for analysis of data quality research. IEEE transactions on knowledge and data engineering, 7(4), p. 623-640. DOI: $10.1109 / 69.404034$

Wang, R.Y-Strong, D.M. (1996): Beyond accuracy: What data quality means to data consumers. Journal of Management Information Systems, 12(4), p. 5-33. https://doi.org/10.1080/07421222 .1996 .11518099

Zödi, Zs. (2015): Elvek és valóság Európában: a PSI-irányelv érvényesülésének problémái. In: Sáry, P. (szerk.): Jogtörténeti és jogelméleti tanulmányok. Miskolc: Miskolci Egyetemi Kiadó, p. 174-185

Zuiderwijk, A. - Helbig, B. - Gil-García, J.R. - Janssen, $M$. (2014): Innovation through Open Data - A Review of the State-of-the-Art and an Emerging Research Agenda. Journal of Theoretical and Applied Electronic Commerce, 9(2), p. 1-8. http://dx.doi.org/10.4067/ S0718-18762014000200001 